\section{Research Article} \\ (C) 2020 Emmanuel Ufuophu-Biri. \\ This is an open access article licensed under the Creative Commons \\ Attribution-NonCommercial 4.o International License \\ (https://creativecommons.org/licenses/by-nc/4.0/)
}

P U B I I S H I II G

Received: 13 January 2020 / Revised: 03 March 2020 / Accepted: 04 March 2020 / Published: 10 March 2020

\title{
Television and Family Unity in South - South Nigeria
}

\section{Emmanuel Ufuophu-Biri}

\author{
Faculty of the Social Sciences, \\ Department of Mass Communication, \\ Delta State University, P.M.B. 1., Abraka, Delta State, Nigeria
}

Doi: 10.36941/mjss-2020-0025

\begin{abstract}
Television plays important role in the family. It serves as source of information, entertainment, cultural propagation, among other functions. It brings family members together and serves as a catalyst for family unity. However, there is the argument that television viewership could also have negative influence on family unity and values. The study therefore investigated the influence of Television viewing on family unity and values in Southern Nigeria. The study adopted the Behavior Imitation, Linkage and Bowen Family Systems theories. The study used survey and questionnaire as method and instrument respectively. The respondents were chosen through a multi-stage sampling process. The data were analyzed using descriptive statistics. The results show that majority of the respondents do not watch television together with other family members at home. Also, watching of television is found to have negative influence on family unity and values. The study recommends that family members should watch television together at home; and avoid adopting negative values they watch on television.
\end{abstract}

Keywords: Family University, Family Values, Television Influence, Television viewership

\section{Introduction}

The Family in Nigeria is a tightly knit whereby the father and mother sit at the helm of affairs. One common feature of the family is the getting together of the members in the evening after the day's deeds and engaging in common activities such as storytelling, playing in-door games, traditional games or every member of the family watching a program on the family's television set. According to Pigeron (2009), the togetherness of the family enables members to share common values, assist one another and adhere to moral principles and practices. Family members, especially the younger ones learn values from the family togetherness just as the family's togetherness helps to build unity among family members.

The unity of the family, especially through the togetherness in the evening, where stories are told, games played or every member glued to one television channel at a time enables family members to be united and to adhere to family values. Family members usually tell the stories of television program they watched the previous night.

Pigeron (2009 p. 56) explains that the "traditional evenings spent together eating around the family's table and telling stories are now long gone". This according to Pigeron, is mainly predicated on the modern proliferation of television and digital communication tools and processes. Villegas (2013) corroborated the view of Pigeron (2009) and explained further that television and other digital 
technologies of communication in the modern era tend to have thrown away family unity and values adding that the family unity and values seem to be gradually eroding as a result of the influence of television and modern digital technologies of communication.

One of the likely major reasons is that unlike in the past where family members watched one television set and one channel at a time, many families at present have more than one television set at home. The multiplicity of television sets enables family members to watch different television channels simultaneous and independently and these television programs could have conflicting interest for family members. The consequence, Zilka and Romi (2018) note, could be members of the family developing different thought structure, philosophy, direction and values which could run counter to cherished family unity and values.

Thus, Villegas (2013) says the invasion of the family by television and digital tools of communication has laid much constraint on parents' control and supervision of their children and wards' media interaction. In this way, family values and unity could be negatively affected. Talty (2015) says cable television channels have the capability to undermine healthy family relationships. Television impacts significantly on family relationship and tends to breakdown family ties and core value (Corcoran 2012, Rideout, Foehr and Roberts, 2012).

\section{$1.1 \quad$ Statement of the Problem}

Television viewership tends to be a factor that could hinder unity in the family and prevent the observance of family values. This could be as a result of family members devoting too much time to television viewing at the expense of dedicating adequate time to discussions and activities that can promote unity in the family and enhance the observance of family and core societal values.

The worry therefore, is that family unity and values could be relegated to the background in favor of watching television. This could affect cordial relationship and create distance in relationship among family members. In the light of the following, it is necessary to examine the influence of television viewership on unity and values of family in South - South geopolitical zone of Nigeria.

\subsection{Scope of the Study}

The study covers South - South Nigeria, comprises - Akwa Ibom, Bayelsa, Cross Rivers, Delta, Edo, Rivers states. The South - South geopolitical zone is one of the six geopolitical zones in Nigeria. The others are South - West, South - East, North - Central North - East and North - West. The South South is the crude oil and gas producing geopolitical zone in Nigeria.

\subsection{Objectives of the Study}

The broad objective of the study is to determine how television viewership influences family unity and values in South - South geopolitical zone of Nigeria. Meanwhile, the specific objectives are to ascertain:

1. the pattern of television viewing by family members in South - South geopolitical zone of Nigeria;

2. the frequency of watching television together at home by family members in South - South geopolitical zone of Nigeria;

3. the influence of television viewership on family unity in South - South geopolitical zone of Nigeria; and

4. the influence of television viewership on family values in South - South geopolitical zone of Nigeria.

\subsection{Research Questions}

1. What is the pattern of television viewing by family members in South - South geopolitical 
zone of Nigeria?

2. What is the frequency of watching television together at home by family members in South - South geopolitical zone of Nigeria?

3. What is the influence of television viewership on family unity in South - South geopolitical zone of Nigeria?

4. What is the influence of television viewership on family values in South - South geopolitical zone of Nigeria?

\section{Literature Review}

Television plays significant roles in the family, ranging from information, enlightenment, entertainment, stimulation and preservation of family and cultural values to socialization process. Folarin (2001) explains that television could serve as a potent unifying factor for members of the family as it brings them together, especially in the evenings, weekends and public holidays.

Other schools of thought feel that television could also be damaging to the family in some way. For instance, Huisman, Edwards and Catapano (2012) argue that though technologies such as television, gaming equipment, the Internet, among other are meant largely for family entertainment, but often times, the use of these technologies, especially television runs counter to family values and unity. This occurs when there is conflict in the viewing interest of family members. This seems to be more common in families that can afford more than one television set and in families where members have access to computers, smart phone, communication tablets, which could provide alternatives to the conventional television.

Kerawalla and Crook (2002) opine that in addition to entertainment purpose, television set is also meant to provide educational values for the children at home. Many parents actually want their children and wards to watch educational and didactic television program but most children prefer entertainment program that do not add significant value to their upward mobility. To ensure compliance with family principles and standards, Shaperd, Arnold and Gilbbs (2006) observe that many family institute guidelines on how digital technologies and television should be used in the home.

Coon and Tucler (2002) assert that television plays both positive and negative roles in the family. It is used for entertainment, information, education, commerce and several other important positive roles. However, television has been found to impact negative on family values and unity. Television watching according to Coon and Tucler (2002), could be time wasting because once at home many family members would spend more time watching television than doing other things. Many family members have thus come to regard television as a better friend and companion than they regard other family members. Additionally, many people have come to regard television as a virtual place which has replaced all physical places.

Thus, many persons, according to Coyne, Padilla-Walker, Fraser, Kaylene, Fellows and Day (2014), prefer watching television alone to visiting friends, colleagues, relations. In this regard, television tends to isolate the individual into his/her individual life which could be counterproductive to family values and unity. For instance, several bad behaviors by children, especially adolescents, are copied from television viewing. Coon and Tucler (2002) note that families now live in a world of two spaces - the reality of life and the pseudo world of television. The pseudo world of television could therefore pose much danger to family unity and values.

Wallace (2015) observes that watching television together strengthens family unity and helps to preserve family values and build strong love and care among family members. Hardy et al. (2006) assert that television is important in the family by providing recreation and education at minimal cost. They note that television could play the role of parents if only the children are exposed to good television program,

Neumark-Sztainer, Story, Ackaro, Moe, Perry (2002) explain that television viewing among family members enhances family love and unity, especially when family members watch television 
together during family meal time. It enables the family to interact positively and friendly in addition to enhancing healthier dietary system in children.

Taylor (2013) observes that television has contributed significantly to the growing division between the traditional roles that parents and their children play. Taylor found that children who spend more time on television and other digital tools of communication indicate that they get less support from their parents. In this sense, television and the digital tools of communication such as the Internet, computer games, etc, tend to provide alternative parenting and escape route for the children.

However, Talty (2015) disagrees that television viewership in the home impacts positively on family relationship and core values. Talty is of the view that to achieve good, productive and functional family relationship, the family needs to devote less time to television viewing and greater time of having fun with the children and other forms of practical human interaction among family members. In the view of Talty, exposure of children to cable television which contains several channels with many of them deviating from family and public taste, could have much negative consequence on family values and cordial family relationship.

In line with view point of Talty, Sorensen (2015) notes that television is one major technology that has the capability of preventing and distorting family communication. Family members could concentrate on watching a particular channel or the members watching different channels at home from different television sets simultaneously, without communicating with one another over a long period of time. This could divide the family and create a negative communication gulf which could be injurious to family unity, love and values.

Chen and Kennedy (2005) observe that the rise of television technology which enables individual to pay more attention to television than to family and group communication has facilitated a negative rise in individualism, decline in family unity and erosion of major family values. Family members now seem to find more solace in watching television rather than engaging in fruitful communication with other family members. Even when the family is seated together, they are more likely to be found watching television and concentrating fully on the program instead of talking to one another. Jordan (2006) also expresses worry that even when family members engage one another in discussion they discuss more of the content of television program instead of core family issues.

The lack of communication among family members created by television could be detrimental to family interaction, unity and values and consequently have negative influence on family relationship. Drago (2015) found a significant correlation between the increasing use of television and depreciating communication and interaction among family members. Drago found that constant television viewing among family members; tend to depreciate their level of interpersonal interaction and communication.

Brignall and van Valey (2005) found that television and the Internet have been so used by individuals to the extent that they prefer interacting with them to interacting with family members. Once at home, many people resort to watching television at the negligence of family members and sometimes, family affairs. Turkle (2012) also found significant relationship between parents distancing themselves from their children and the use of television. The finding shows that many children confessed that their parents were obsessed with television and other digital tools of communication at the detriment of the children.

DuRant, Rich, Emans, Rome, Allred and Wood (1997) report that some television contents viewed in the family portray overt violence which many children regard as real and actually want to copy. Good examples are the videos shown on music television station which seem to permit the carrying and usage of deadly weapons, drugs and alcohol. Many parents are unable to effectively educate their children that the pseudo world of the music television videos is totally different from the actual world reality. Arising from the seemingly negative impact of television on the family, Cantor (1999) recommends that parents should control the program their children and wards are exposed to. To achieve a control, parents should use television ratings system to prevent children from watching violent and sexually provocative television program. 
Piotrowski, Jordan, Bleakley and Hennessy (2015) found that spending too much time on television viewing is not too healthy for children's development and the preservation of family values and unity. Brignall and van Valey (2005) found that many children spend more time watching television at home than doing other things. The children interact with television more than they interact with other family members.

The foregone review seems to largely indicate that television plays in significant role in family unity and preservation of family values. The role could either be positive or negative.

\subsection{Theoretical Framework}

The study adopts the Behavior Imitation, Linkage and Bowen Family Systems theories. The Behavior Imitation Theory postulates that the mass media audience, especially children, tend to learn or imitate much of the contents of the mass media, especially television. Such contents mainly pertain to violence and other deviant acts. Folarin (2001) explains that the Imitation Behavior Theory assume that the audience, young people learn immensely from what they watch on Television. However, they are more inclined to imitating the violence and other contents which tend to lower public taste. The theory therefore holds strongly that audience learns and imitates significantly the violence and deviant acts they watch on television.

The Linkage Theory also assumes that television audience, particularly children always exhibit the tendency to link the fantasy, violence and other contents they watch on Television with real life situation. This linkage between the pseudo world of Television fantasy and violence on the one hand and real life on the other hand tend to encourage the audience, particularly young people to want to imitate what they want on Television, and which in most case does not conform to societal expectation, standard and acceptance. The above two theories are relevant to this study in the sense that the work deals with the influence of television on family values.

The Bowen Family Systems Theory propounded by Murray Bowen, postulates that the family is the center of activities and the controlling force and determinant of the emotional development of family members. The theory explores the significance of the family on the emotional, cognitive, psychological and physiological state and pattern of the individual members of the family. Bowen (1992) asserts that the theory recognizes the family as an organic unit, within which the individual members should behave and function in accordance with the established family principles and rules. The theory also sees the family as an emotional unit that helps to manage the individual and collective emotional state of members in order to attain and maintain collective emotional development and social identity.

The theory while recognizing the independence and individuality of family members places emphasis on the collectivism of the family as the core and power unit. The family is therefore the centrality of activity and emotional determinant for members. The theory is relevant to this study because the work is concerned with the influence of television on family unity, taking cognizance of the fact that the Family System theory recognizes the family as a strong and binding emotional and physical unit.

\section{Materials and Methods}

The study adopted the descriptive design. Survey method and questionnaire were used as the method and instrument respectively to gather the data. The respondents were chosen from the six states that comprise the South - South geopolitical zone of Nigeria. The states are Akwa Ibom, Bayelsa, Cross Rivers, Delta, Edo and Rivers. A total of 4,980 respondents from 978 families were chosen through multi-stage sampling technique across the South - South geopolitical zone to participate in the study. The questionnaire was administered to 830 participants across 163 families in each of the participating six states. Likert scale was used whereby the items were scored in the following order: Strongly agree (SA), Agree (A), Disagree (D) and Strongly Disagree (SD). For positively worded items, 
the weightings were 4, 3, 2 and 1 and the negatively worded items were scored 1, 2, 3, and 4. The questionnaire has four components:

1. Component one investigated how the family members watch television together at home. It yielded Cronbach alpha reliability of 0.90 .

2. Component two interrogated the number of hours the families spend a week watching television and yielded Cronbach alpha reliability of 0.89 .

3. Component three which investigated influence of television on family unity yielded Cronbach alpha reliability of 0.92 .

4. Component four which interrogated the influence of television on family values yielded Cronbach alpha reliability of 0.93 .

In order to determine the reliability of the instrument a pre-test was carried out on 20 respondents in Enugu, which is outside the scope of this study. The Statistical Package for Social Sciences (SPSS) version 20.0 was used to run the data gathered for reliability test.A Cronbach alpha of 0.91 was obtained.

\subsection{Procedure}

Trained research assistants were hired to administer the copies of the questionnaire. The administration and retrieval of the instrument span about six weeks.

The recent assistants were selected from their states of origin so that they could be more familiar with the respondents. The respondents were approached and informed that the research was basically for academic purpose and that their individual identities would be protected. The participants also got instructions on how to fill the instrument. A total of 4,870 copies of the questionnaire were returned accounting for $97.79 \%$

The data were analyzed using tables, percentages and means. A rating scale of $0-4$ based on the Likert scale was developed to measure the level of influence of television viewership on family unity and family values.

\section{Results and Discussion}

Table 1: How family members watch television at home

\begin{tabular}{|l|c|c|}
\hline Pattern of Watching television in the family & Frequency & Percentage \\
\hline Watch television individually & 400 & 8.21 \\
\hline Watch television together & $\mathbf{1 , 0 2 0}$ & $\mathbf{2 0 . 9 4}$ \\
\hline Separate television for children & 860 & 17.66 \\
\hline Separate television for adults in the family & 680 & 13.96 \\
\hline Separate television for guests & 430 & 8.83 \\
\hline Separate for husbands and wives & 680 & 13.96 \\
\hline Separate television for husbands & $\mathbf{2 9 0}$ & 5.95 \\
\hline Separate television for wives & 310 & 6.37 \\
\hline Separate for domestic staff & $\mathbf{2 0 0}$ & 4.11 \\
\hline Total & $\mathbf{4 , 8 7 0}$ & $\mathbf{1 0 0} \%$ \\
\hline
\end{tabular}

For instance, $8.2 \%$ watched television individually; $20.9 \%$ watched television together with other family members; $17.7 \%$ had separate television sets for the children; $14.0 \%$ had separate television sets for adults; $8.8 \%$ had separate television sets for guests. Also, $14.0 \%$ respondents said there were separate television sets for the husbands and wives in the family; $6.0 \%$ respondents said their families maintain separate television sets for the husbands; $6.4 \%$; and $4.1 \%$ reported maintaining separate television sets for wives and domestic staff respectively.

The result shows that only $20.9 \%$ of the respondents watch television together with other 
members of the families. The finding therefore suggests that most of the family members in South South geopolitical of Nigeria that participated in the study do not watch television together. The finding is in line with the postulations of Pigeron (2009), Villegas (2013), Kerawalla and Crook (2002) which hold that family members have different patterns of watching television at home.

Table 2: Hours spent in a week watching television together in the family

\begin{tabular}{|c|c|c|}
\hline Hours spent weekly watching together TV in the family & Frequency & Percent \\
\hline $1-2$ hours & 570 & 11.70 \\
3-4 hours & 3,030 & 62.21 \\
$5-6$ hours & 910 & 18.69 \\
7 hour and above & 360 & $7 \cdot 39$ \\
\hline
\end{tabular}

We used weekly watching of television to measure the frequency of watching television together by the family members. The result shows that majority of the respondents $-62.68 \%$ watch television with other family members at home between three and four hours in a week; $18.68 \%$ reported spending between five and six hours daily watching television together in the family in a week; $11.70 \%$ spend between one and two hours weekly watching television with other family member; and $6.78 \%$ spend seven hours and above weekly watching together television at home. The result suggests that family members in South - South geopolitical of Nigeria spend between three and four hours weekly watching television together at home. The finding agrees with those of Coon and Tucler (2002), Brignall and van Valey (2005), Coyne, et al (2014), Piotrowski, et al (2015) which found that many family members spend more time watching television alone than watching together with other family members.

Table 3: Influence of Television on Family Unity

\begin{tabular}{|c|c|c|c|c|c|c|c|}
\hline $\mathbf{S} / \mathbf{N}$ & Influence of watching television on unity in the family & $\mathbf{N}$ & SA & A & $\mathbf{D}$ & SD & $\begin{array}{c}\text { Mean } \\
(\pi)\end{array}$ \\
\hline 1. & $\begin{array}{l}\text { Choice of television channel causes disagreement in my } \\
\text { family. }\end{array}$ & 4,870 & $\begin{array}{c}2230 \\
(45.8 \%)\end{array}$ & $\begin{array}{c}1350 \\
(27 \cdot 7 \%)\end{array}$ & $\begin{array}{c}870 \\
(17 \cdot 9 \%) \\
\end{array}$ & $\begin{array}{c}420 \\
(8.6 \%) \\
\end{array}$ & 3.1068 \\
\hline 2. & $\begin{array}{l}\text { I watch some programs at home because I have no control } \\
\text { of the television. }\end{array}$ & 4,870 & $\begin{array}{c}3020 \\
(62.0 \%) \\
\end{array}$ & $\begin{array}{c}840 \\
(17.2 \%) \\
\end{array}$ & \begin{tabular}{c|}
540 \\
$(11.1 \%)$
\end{tabular} & $\begin{array}{c}470 \\
(9.7 \%) \\
\end{array}$ & $3 \cdot 3162$ \\
\hline 3. & $\begin{array}{l}\text { I endure watching television programs with my family } \\
\text { members, even when I don't like the programs. }\end{array}$ & 4,870 & $\begin{array}{c}1310 \\
(26.9 \%)\end{array}$ & $\begin{array}{c}2830 \\
(58.1 \%)\end{array}$ & $\begin{array}{c}590 \\
(12.1 \%)\end{array}$ & $\begin{array}{c}140 \\
(2.9 \%)\end{array}$ & 3.0903 \\
\hline 4 . & $\begin{array}{l}\text { We discuss less of family issues than we discuss television } \\
\text { programs. }\end{array}$ & 4,870 & $\begin{array}{c}1960 \\
(40.2 \%)\end{array}$ & $\begin{array}{c}1500 \\
(30.8 \%) \\
\end{array}$ & $\begin{array}{c}990 \\
(20.3 \%)\end{array}$ & $\begin{array}{c}420 \\
(8.6 \%)\end{array}$ & 3.0267 \\
\hline 5 . & $\begin{array}{l}\text { dren and parents do not watch same programs } \\
\text { always. }\end{array}$ & 4,870 & $\begin{array}{c}2130 \\
(43.7 \%) \\
\end{array}$ & $\begin{array}{c}1350 \\
(27 \cdot 7 \%) \\
\end{array}$ & $\begin{array}{c}970 \\
(19.9 \%) \\
\end{array}$ & $\begin{array}{c}420 \\
(8.6 \%) \\
\end{array}$ & 3.0657 \\
\hline 6. & $\begin{array}{l}\text { The family always does not always agree over television } \\
\text { parental control. }\end{array}$ & 4,870 & $\begin{array}{c}3090 \\
(63.4 \%) \\
\end{array}$ & \begin{tabular}{c|}
520 \\
$(10.7 \%)$ \\
\end{tabular} & $\begin{array}{c}630 \\
(12.9 \%) \\
\end{array}$ & $\begin{array}{c}630 \\
(12.9 \%) \\
\end{array}$ & 3.2875 \\
\hline 7. & Lack of subscription causes quarrel in the family. & 4,870 & $\begin{array}{c}980 \\
(20.1 \%) \\
\end{array}$ & $\begin{array}{c}2910 \\
(59.8 \%) \\
\end{array}$ & $\begin{array}{c}590 \\
(12.1 \%) \\
\end{array}$ & \begin{tabular}{c|}
390 \\
$(8.0 \%)$ \\
\end{tabular} & 2.9199 \\
\hline 8. & $\begin{array}{l}\text { Choice of television channel has caused physical fight in } \\
\text { the family. }\end{array}$ & 4,870 & $\begin{array}{c}380 \\
(7.8 \%)\end{array}$ & \begin{tabular}{c|}
260 \\
$(5 \cdot 3 \%)$ \\
\end{tabular} & $\begin{array}{c}2380 \\
(48.9 \%) \\
\end{array}$ & $\begin{array}{c}1850 \\
(38.0 \%) \\
\end{array}$ & 1.8296 \\
\hline 9 . & $\begin{array}{l}\text { We watch different programs simultaneously in the family } \\
\text { on different television sets. }\end{array}$ & 4,870 & $\begin{array}{c}2750 \\
(56.5 \%) \\
\end{array}$ & $\begin{array}{c}620 \\
(12.7 \%) \\
\end{array}$ & $\begin{array}{c}640 \\
(13.1 \%) \\
\end{array}$ & $\begin{array}{c}860 \\
(17 \cdot 7 \%) \\
\end{array}$ & 3.1191 \\
\hline \multirow[t]{2}{*}{10.} & $\begin{array}{l}\text { Choice of television program or channel has caused enmity } \\
\text { in the family. }\end{array}$ & 4,870 & $\begin{array}{c}810 \\
(16.6 \%)\end{array}$ & $\begin{array}{c}780 \\
(16.0 \%) \\
\end{array}$ & $\begin{array}{c}2270 \\
(46.6 \%)\end{array}$ & $\begin{array}{c}1010 \\
(20.7 \%)\end{array}$ & 3.3162 \\
\hline & TOTAL & & & & & & 3.0078 \\
\hline
\end{tabular}


The result above shows that the overall mean $(\pi)$ of the parameters used to test the influence of television viewership on family unity indicates that television viewership has negative influence on family unity among the respondents. For instance, the cumulative mean $(\pi)$ of 3.0007 over a total of o-4 scale, where the overall mean is 4.0 , also shows that television viewership does not promote unity in the family rather it influences disunity among family members in South - South geopolitical of Nigeria.

The findings agree with those of Pigeron (2009); Talty (2015); Taylor (2013); Drago (2015); Brignall and Vanley (2005), that television creates disunity in the family.

Table 4: Influence of Television on Family Values

\begin{tabular}{|c|c|c|c|c|c|c|c|}
\hline $\mathbf{S} / \mathbf{N}$ & Influence of watching TELEVISION on family values & $\mathbf{N}$ & SA & A & $\mathbf{D}$ & SD & Mean $(\pi)$ \\
\hline 1. & $\begin{array}{l}\text { The family does not forbid sexually provocative } \\
\text { television programs. }\end{array}$ & 4,870 & $\begin{array}{c}2,230 \\
(45.8 \%)\end{array}$ & \begin{tabular}{|c|}
1,350 \\
$(27.7 \%)$
\end{tabular} & $\begin{array}{c}870 \\
(17.9 \%)\end{array}$ & \begin{tabular}{|c|}
420 \\
$(8.6 \%)$
\end{tabular} & 3.1068 \\
\hline 2. & $\begin{array}{l}\text { I want to practice the sexually provocative programs I } \\
\text { watch on television. }\end{array}$ & 4,870 & $\begin{array}{c}2730 \\
(56.1 \%)\end{array}$ & $\begin{array}{c}990 \\
(20.3 \%)\end{array}$ & $\begin{array}{c}600 \\
(12.3 \%)\end{array}$ & $\begin{array}{c}550 \\
(11.3 \%)\end{array}$ & 3.2115 \\
\hline 3. & $\begin{array}{l}\text { I practice the sexually provocative programs I watch on } \\
\text { television }\end{array}$ & 4,870 & $\begin{array}{c}920 \\
(18.9 \%)\end{array}$ & \begin{tabular}{c|c|}
1000 \\
$(20.5 \%)$
\end{tabular} & $\begin{array}{c}1090 \\
(22.4 \%)\end{array}$ & $\begin{array}{c}1860 \\
(38.2 \%)\end{array}$ & 2.2012 \\
\hline 4. & $\begin{array}{l}\text { I watch violent television programs when there is } \\
\text { nobody to prevent me. }\end{array}$ & 4,870 & $\begin{array}{c}2,750 \\
(56.5 \%)\end{array}$ & $\begin{array}{c}620 \\
(12.7 \%) \\
\end{array}$ & $\begin{array}{c}630 \\
(12.9 \%)\end{array}$ & $\begin{array}{c}860 \\
(17.7 \%)\end{array}$ & 3.1191 \\
\hline 5. & I like to practice the violence I watch on television & 4,870 & $\begin{array}{c}240 \\
(4.9 \%) \\
\end{array}$ & \begin{tabular}{|c|}
2670 \\
$(54.8 \%)$ \\
\end{tabular} & $\begin{array}{c}1030 \\
(21.1 \%)\end{array}$ & $\begin{array}{c}930 \\
(19.1 \%) \\
\end{array}$ & 2.4559 \\
\hline 6. & I enjoy violent television programs. & 4,870 & $\begin{array}{c}2770 \\
(56.9 \%) \\
\end{array}$ & \begin{tabular}{c|c|}
600 \\
$(12.3 \%)$
\end{tabular} & $\begin{array}{c}770 \\
(15.8 \%)\end{array}$ & \begin{tabular}{|c|}
720 \\
$(14.8 \%)$ \\
\end{tabular} & 3.1520 \\
\hline 7 . & The family prefers watching television to storytelling. & 4,870 & $\begin{array}{c}2690 \\
(55.2 \%)\end{array}$ & $\begin{array}{c}840 \\
(17.2 \%)\end{array}$ & $\begin{array}{c}740 \\
(15.2 \%)\end{array}$ & $\begin{array}{c}600 \\
(12.3 \%)\end{array}$ & 3.1540 \\
\hline 8. & $\begin{array}{l}\text { The family prefers watching television to attending to } \\
\text { family matters. }\end{array}$ & 487 & $\begin{array}{c}2790 \\
(57 \cdot 3 \%) \\
\end{array}$ & $\begin{array}{c}840 \\
(17.2 \%)\end{array}$ & $\begin{array}{c}570 \\
(11.7 \%)\end{array}$ & $\begin{array}{c}670 \\
(13.2 \%)\end{array}$ & 3.1807 \\
\hline 9. & Watching television makes me want to be less honest. & 487 & $\begin{array}{c}2830 \\
(58.1 \%) \\
\end{array}$ & $\begin{array}{c}890 \\
(18.3 \%)\end{array}$ & $\begin{array}{c}660 \\
(13.6 \%)\end{array}$ & \begin{tabular}{|c|}
490 \\
$(10.1 \%)$
\end{tabular} & 3.2444 \\
\hline 10. & $\begin{array}{l}\text { Television watching makes me to be less participative in } \\
\text { family team activities. }\end{array}$ & 487 & $\begin{array}{c}2840 \\
(58.3 \%)\end{array}$ & \begin{tabular}{|c|}
880 \\
$(18.1 \%)$
\end{tabular} & $\begin{array}{c}580 \\
(11.9 \%)\end{array}$ & $\begin{array}{c}570 \\
(11.7 \%)\end{array}$ & 3.2300 \\
\hline 11. & Television watching makes me to be less compassionate. & 487 & $\begin{array}{c}1,410 \\
(29.0 \%)\end{array}$ & $\begin{array}{c}2,520 \\
(51.7 \%) \\
\end{array}$ & $\begin{array}{c}330 \\
(6.8 \%) \\
\end{array}$ & $\begin{array}{c}610 \\
(12.5 \%) \\
\end{array}$ & 2.9713 \\
\hline 12. & $\begin{array}{l}\text { I spend more time watching television than I spend on } \\
\text { family matters and members }\end{array}$ & 4,870 & $\begin{array}{c}1,750 \\
(35.9 \%)\end{array} \mid$ & \begin{tabular}{|c|}
2,430 \\
$(49.9 \%)$
\end{tabular} & $\begin{array}{c}460 \\
(9.4 \%)\end{array}$ & $\begin{array}{c}230 \\
(4.7 \%)\end{array}$ & 3.1704 \\
\hline 13. & Watching television makes me to be less humble. & 4,870 & $\begin{array}{c}2,760 \\
(56.7 \%)\end{array}$ & $\begin{array}{c}930 \\
(19.1 \%)\end{array}$ & $\begin{array}{c}620 \\
(12.7 \%)\end{array}$ & $\begin{array}{c}560 \\
(11.5 \%) \\
\end{array}$ & 3.2094 \\
\hline 14. & Watching television makes me to be less generous. & 4,870 & \begin{tabular}{|c|}
2,920 \\
$(60.0 \%)$
\end{tabular} & $\begin{array}{c}530 \\
(10.9 \%) \\
\end{array}$ & $\begin{array}{c}690 \\
(14.2 \%) \\
\end{array}$ & \begin{tabular}{|c|}
730 \\
$(15.0 \%)$
\end{tabular} & 3.1951 \\
\hline 15. & Watching television makes me to be impatient. & 4,870 & \begin{tabular}{|c|}
2,780 \\
$(57.1 \%)$
\end{tabular} & \begin{tabular}{|c|}
950 \\
$(19.5 \%)$ \\
\end{tabular} & $\begin{array}{c}580 \\
(11.9 \%) \\
\end{array}$ & $\begin{array}{c}560 \\
(11.5 \%)\end{array}$ & 3.2218 \\
\hline & TOTAL & & & & & & 3.0549 \\
\hline
\end{tabular}

The result on table 3 indicates that watching of Television has negative influence on family values among family members in South - South geopolitical of Nigeria. For instance, the values of the 15 parameters used to determine the influence of television viewership on family values show that television viewership has negative influence on the respondents. The cumulative mean $(\pi)$ for the 15 parameters is 3.0549 over a total of $0-4$ scale, where the overall mean is 4.0 ; clearly suggests that television viewership has negative influence on family values in South - South geopolitical of Nigeria. The findings are in tandem with those of Villegas (2013); Huisman et al (2012); Kerawalla and Crook (2002); Hardy et al (2006); Turkle (2012); Durant et al; and Piotrowski et al (2015) which hold that television viewership tends to lower family values. 
The finding also agrees with the adopted theories - Imitation Behaviour, Linkage Theory and Bowen Family Systems theories. The fundamental assumption of the first two theories is that the audience of the mass media, especially Television is prone to learning from the fantasy, violence and deviance on television. The Bowen Family Systems theory assumes that the family is central of emotional determinant and control among family member. Therefore, an interference with the control of the family could affect family values.

\section{Conclusion}

The studies found television viewership to have significant influence on family unity in South - South geopolitical of Nigeria. Many family members dedicate more time to watching television at home than they dedicate to other family issues, a situation that implies relegation of family matters to the background in favor of television viewership. The study also clearly indicates that majority of family members in South - South geopolitical of Nigeria do not watch television together. Some families have different television sets for the children, husband, wives, guests and domestic staff. The findings suggest therefore, that majority of family members in South - South geopolitical of Nigeria are not united by television viewership as different members of the family have independence of choice of television viewership and actual separate television sets. The findings also imply that television viewership has negative influence on family unity among residents in South - South geopolitical of Nigeria. Additionally, the findings suggest that television viewership has negative influence on family values in South - South geopolitical of Nigeria. The study thus implies that television viewership has negative influence on family unity in South - South geopolitical of Nigeria.

\subsection{Recommendations}

Families should watch television together at home to promote unity in the family; families should identify conflicts in the family that arise from viewing television and find ways to avoid them; and Family members should learn positive values from television instead of the negative values.

\section{References}

Bowen, M (1992). Family Therapy in Clinical Practice. North Vale, NJ: Jason Aronson, Inc.

Brignall, T.W., \& van Valey, T. (2005). The Impact of Internet Communications on Social Interaction. Sociological Spectrum, 25 (3) 335-348.

Cantor J. (1998). "Mommy, I'm Scared": How television and Movies Frighten Children and What We Can Do to Protect Them. New York, NY: Harcourt Brace; 1998

Chen, J.L. \& Kennedy, C. (2005). Cultural Variations in Children's Coping Behavior, TELEVISION Viewing and Family Functioning. International Nursing Review (52) 193, 186-199

Coon, K.A and Tucker, K.L. (2002). Television and Children's Consumption Pattern. A Review of Literature. Minerva 54 (5) 423-36

Corcoran, M. (2012) The Impact of New Media Technologies on Social Interaction in the Household. Retrieved 20 February, 2016 from: http://www.maynoothuniversity.ie/sites/default/files/assets/document /siobhanMcGrath/html

Coyne, S.M., Padilla-Walker, L.M., Fraser, A.M., Fellows, K., and R.D. Day (2014). "Media Time = Family Time": Positive media use in families with adolescents. Journal of Adolescent Research Vol. 29(5) 663-688

DuRant, R.H., Rich, M, Emans, S.J., Rome E.S., Allred E., Woods, E.R. (1997). Violence and Weapon Carrying in Music Videos: A Content Analysis. Arch Pediatric Adolescent Med. 151:443-448

Emily Drago, E. (2015). The Effect of Technology on Face-to-Face Communication.

Folarin, B. (2001). Theories of Mass Communication: An Introductory Text Abeokuta: link publications.

Hardy, L.L, Baur, L.A, Garnett, Crawford D, Campbell, K.J, Shrewsbury, V.A,. Cowell, C.T., and Salmon, J. (20o6). Family and Home Correlates of Television Viewing 12-13 year old Adolescents: The Nepean Study. International Journal of Behaviour Nutrition and Physical Activities, 3(1), 1- 10 
Huisman, S, Edwards, A and Catapano, S. (2012). The Impact of Technology on Families. International Journal of Education and Psychology in the Community. 2(1), 44-62.

Jordan, A. B. (2006). Family Context and Children's Media Use. National Institute of Child Health \& Human Development. Retrieved 20 February, 2016 from: http:// www.nichd.nih.gov/about/meetings/2006 /electronicmediaconf/ jordan_abstract.cfm

Kerawalla, L. and Crook, C. (2002). Children Computer Use at Home and at School: Context and Continuity. British Educational Research Journal, 28(6), 751-771.

Newmark - Sztainer, D, Story M., Ackard, D, Moe, J. and Perry, C (200o). Family Meals among Adoelscents: Findings from a Pilot Study. Journal of Nutritional Education. 32(6), 335-40.

Pigeron, E. "Here's the Deal". Socialization into Morality through Negotiation of Media Time Use. Paper presented at the annual meeting of the international communication association, Marriott, Chicago, IL, 1-37.

Piotrowski, J.T., Jordan, A.B., Bleakley, A., and Hennessy, M. (2015). Family Identifying Television Practices to Reduce Children's Television Time. Journal of Family Communication. (15), 2,159-174

Rideout, V., Foehr, U., \& Roberts, D. (2010). Generation M2: Media in the Lives of 8- to 18-year-olds: A Kaiser Family Foundation Study. Menlo Park, CA: Henry J. Kaiser Family Foundation. Retrieved 21 February from: http://www.kff.org/ entmedia/upload/8o10.pdf

Shepherd, C; Arnold, M, and Gribbs, M. (2006). Parenting in the Connected Home. Journal of Family Studies. 12(2), 203-222.

Sorensen, B (2015). How Does Technology Affect Family Communication? Retrieved 21 February, 2016 from:http://www.livestrong.com/article/24328o-how-does-technology-affect-family-communication/

Talty, C. (2015). Healthy Family Relationship Needs Less televisionTime, More Fun with Kids. Retrieved 20 February 2015 from: http://healthy.family.org/healthy-family-relationship/html.

Taylor, (2013). Is Technology Creating a Family Divide? Retrieved 21 February, 2016 from: https://www.psychologytoday.com/blog/the-power-prime/201303/is-technology-creating-family-divide, The Elon Journal of Undergraduate Research in Communications, (6) 1. 23-38

Turkle, S. (2012). Alone together: Why We Expect More from Technology and Less from Each Other. New York, NY: Basic Books.

Villegas, A. (2013) The Influence of Technology on Family Dynamics. Proceeding of the $70^{\text {th }}$ New York State Communication Association.

Wallace, J.B. (2015) Watch television with Your Family. The Wall street Journal.

Zilka, G.C. and Romi, S.(2018). Viewing habits and identification with television characters among at-risk and normative children and adolescents. International Journal of Child, Youth and Family Studies. 9(3): 47-67 